\title{
THE UNIVERSITY AND THE PROFESSION
}

\author{
Professor J Adamson*
}

This address was given at the Second Annual Legal Conference, held at Wellington, 3-5 April 1929. It followed an address by the then Attorney-General T K Sidey on legal education, an address which not only summarised the meagre nature of formal educational requirements to become a New Zealand lawyer, but directly compared them to that in the United States.

No apology, I feel sure you will agree, is due by your Committee for putting this subject on the agenda paper for discussion.

Some of you may have forgotten so much of your Constitutional History as to fail to remember a meeting of the King, Lords and Commons in the 15th century has been, throughout the ages, branded as the "unlearned" Parliament because lawyers were excluded from it. But you are all aware that in that best known and most august of all modern political institutions - the Mother of Parliaments - members of the legal profession are still addressed respectfully as "the noble and learned Lord" and "the honourable and learned Member" in the respective Houses to which they belong. It is not for nothing that lawyers have thus been singled out. Many names will readily occur to you of those who have combined high academic distinction with conspicuous professional success. I recall at random a few learned holders of the highest judicial office who have acquired pre-eminence not only in law and politics, but also in other fields, and have left their footprints on the sands of time. In the 16th century, Bacon, that inexplicable personality who may be forgiven much because of his services to literature and science; at the beginning of the 19th century, Brougham, of whom it has been said, no doubt by a mordant wit, that, if he had known a little about law he would have known a little about everything; in the 20th century, Haldane, who will probably be known to future generations rather as an expert authority on military organisation than as a brilliant exponent of philosophic theory. Birkenhead, after attaining a position in his profession which would have satiated the ambition of most

- Professor of Law, Victoria University College. The address was first published at [1929] NZLJ 186. 
men, has sought new worlds to conquer where his many sided accomplishments may produce still more popular, if not greater, achievements than a reform of the English Law of Property.

But the subject covers so vast a field that it would be impossible for me in the time at $\mathrm{my}$ disposal this morning to mark out its confines, far less to explore it fully.

I can only touch on one phase of the subject, and therefore my theme will be this: "There is, on the one hand, too much University, and, on the other, too little University in the profession". Paradoxical though this statement may at first sight seem, the paradox will, I think, disappear when it is noted that the word "University" is used in two senses. Until hundred years ago a University would, I venture to suggest, have been understood almost all the world over to mean a seat of learning where those desirous of improving their minds sought erudition by means of personal and direct instruction from professors who were recognised as masters of some particular branch of knowledge, and by contact with their fellow students. And such is still the current conception in all but English-speaking countries. In some of these, however, a University has come to be regarded as an institution - a body without a soul - and, so to speak, without a local habitation, existing merely as an intermediary between examinees and examiners, to the latter of whom the former are mere ciphers. It would be interesting to trace the origin of this view, so divergent is it from the earlier notion. I think it arose in connection with the foundation of the University of London, a century ago, or rather, in its first reorganisation in 1836, when for various reasons, which need not be discussed here, the University was dissociated from the University College as a teaching body and its activities were confined to the holding of examinations and the conferring of degrees. It was probably originally intended that such degrees should be conferred on students of the two teaching institutions then incorporated with the University, but the new charter was couched in language that implied no limitation, and in practice degrees were conferred on all and sundry who qualified by examination. But it was never suggested that this was an ideal arrangement or that it was anything more than a temporary makeshift.

However that may be, it served as a model for Colonial and Indian institutions which were subsequently established. It must not, however, be thought that those who were responsible for the introduction of University education in New Zealand were unaware of the distinction, because, as I am given to understand, they considered but rejected, rightly or wrongly, for good or ill, a scheme to send students to the old Universities at Home. But there arose those who knew not Joseph, and there came to prevail in this country the view that anyone who had obtained a degree from the local University could claim to have had a University education, and passing an examination became an end in itself. When the Judges turned the examination for the entrance to the profession over to the University the transformation was complete. So strongly has this impression prevailed that recently when it was felt that all was not well in the profession the only thing, apart from the 
rearrangement of subjects, that was done was to require more "University" in the shape of additional examinations. This had led to some curious and interesting results. A solicitor has now to undergo a longer, if not more strenuous, examination in Property and Contracts than does a candidate for Honours in Law. His examinations, if taken continuously, would last longer than a workman's week, and would, I venture to think, greatly exceed those for admission to the profession in any other country and less resemble them than the celebrated examination system of China.

Although ridicule has sent the latter to perdition, the comparison is so pertinent that I crave your indulgence while I paraphrase a passage from the Wallet of Kai-Lang, in which it is described or parodied. The author tells how a mild and studious youth from the country came to town to sit the examination, and how, after politely refusing an offer of impersonation - a thing not unknown in New Zealand - he presents himself at the examination hall, or, as it was in this case, the examination cell, and then goes on to say that "each day of the examination the candidate was found alternately elated or depressed according to the length and style of the essay which he had written whilst enclosed in his solitary examination cell. The trials each lasted a complete day, and long before the fifteen days, which composed the full examination, were passed Ling found himself half regretting that he had not accepted the (above-mentioned) offer or even reviling the day on which he had abandoned the hereditary calling of his ancestors." However, when after all was over he came to deliberate with himself on his chances of attaining a degree he could not disguise from his own mind that he had well-formed hopes. He was not conscious of any undignified errors, and he had been able to introduce curious knowledge which he possessed by means of his exceptional circumstances. When the results were published his name did not appear on the list of successful candidates, but it was announced that his papers were "of a most versatile and conflicting order, so that, indeed, the accomplished examiners were unable to decide whether they were very good or very bad. It is clearly impossible to place the expert and inimitable Ling amongst the foremost, nor would it be safe to pass over his efforts without reward". He was accordingly told to appear before the examiners again, and when he did so he was informed by them that nothing remains to be made known except the result of "our despicable efforts to come to an agreeable conclusion. In this we have been successful, and now desire to notify the result", and this was the appointment of this gentle youth, who only desired some pleasant and unambitious civil office, to the command of a valiant and bloodthirsty band of archers.

It is scarcely necessary to point the moral - there was another recruit to the army of misfits.

On the other hand, we have too little University in the proper sense of the term. When the University of New Zealand was established no provision was made for the teaching of Law. Probably it was felt that that spirit of self-reliance which is a conspicuous and 
almost necessary characteristic of early settlers would overcome the need for tuition. Whilst the keeping of terms was from the first a pre-requisite in other faculties, it was otherwise in the Law. It was only comparatively recently that this requirement was insisted on, first for the academic and then for the professional subjects. Even then, if a person had the good fortune to reside in a University district where no provision was made for teaching or more than ten miles from a University centre in which there was, or the misfortune to be engaged in earning his livelihood during the hours when classes were held, he could acquire his knowledge how he would subject to the somewhat strange requirement that he passed a college examination a week or two before he sat that of the University. A few years ago even this requirement was abolished (though it has since been reimposed). I have known at least one case of a student who had commenced by attending at college, but who, when he saw that it was extremely unlikely that he would satisfy his teacher as to his fitness to sit for the University examination, betook himself beyond the ten miles radius where he could defy any attempt by his teacher to test his mental qualification to obtain his degree. Recently a graduate who proposed sitting for Honours, believing that it was necessary to attend College for this purpose, intimated his intention to enrol, but on learning that this was not so, determined to gain the palm by his own unaided efforts.

Although the University was established in the early "seventies" it was not till about 1900 that any serious attempt was made to provide for the teaching of Law at any of the colleges, and although all subjects are now taught in all colleges, the circumstances in which some of the appointments have been made do not, in my opinion, augur well for the advancement of legal learning. One wonders what would the medical profession have said of the appointment of one, however brilliant he may have been as a student or successful as a general practitioner, who had not and did not pretend to have any special knowledge or experience of the subject which he had been selected to teach. The answer, I conceive, would be that such an appointment would, without the slightest personal reflection, render no little disservice to the cause of University education.

Again, it is a matter of grave concern that among candidates for the Law degree the number of those who have a degree in Arts is gradually decreasing. Indeed they have practically disappeared. That many who enter the profession should content themselves with a purely vocational training is, under present circumstances, only to be expected, but, in order that it should be prevented from sinking to a mere trade, it is essential that it should have a nucleus of members who have received a higher general education than that merely evidenced by the passing of the matriculation examination. This is all the more necessary because here there is no hard and fast line drawn between barristers and solicitors, for where such distinction does exist it tends to produce and maintain a better standard. I do not mean to suggest that in every case a barrister has greater natural gifts or has received a better education than a solicitor, but it is an undoubted fact that a higher standard prevails 
in the one branch than the other. Where no such differentiation is made it is of the utmost importance to see that the lower standard does not become the only standard.

Though the statement may seem strange coming from a Professor, I firmly and strongly believe that we have far too many law graduates of the present type, and I should hazard the guess, which, however, I have not been able to verify by statistics, that the proportion of University graduates to non-graduates in the profession is greater in New Zealand than in any other country. The doubtful advantages of such a state of things is, I think, outweighed by the positive disadvantages, the principal of which is that under the present system of examination it reduces the level of intellectual achievement in the profession. In this matter I regret to say the profession has not received any encouragement from the University. Some years ago it was suggested that Roman Law should, as is the case in some Universities, be included amongst the Arts subjects, an inclusion which would have induced more Law students to have taken an Arts degree. Not only was this proposal rejected, but shortly afterwards the subjects of Jurisprudence and Constitutional History were struck out of the Arts curriculum and the two degrees have been completely divorced. It is, therefore, a matter of serious consideration for a student to take his Arts course before the Law course, though some have endeavoured to take them simultaneously - a proceeding which is not without its drawbacks, but which is more satisfactory than taking Arts after Law. It is inconceivable that one can acquire a thorough understanding of the law of his own country unless he knows something more than he learns at school - if he has there learned anything at all - of its political, social and economic history. And what of these conditions in other countries, and in particular of that Empire whose law, in its final form, has been a force in civilisation second only to that of Christianity itself? May I add that a knowledge of the classics, perhaps more than is the case with any modern foreign languages, enables one to obtain, as Viscount Bryce puts it, that more exact comprehension of the words, phrases and idioms of his own language which is of such importance to those engaged in the legal profession.

You my ask, and I think you are entitled to ask, how these things are to be remedied. I suggest - though I claim no originality for the suggestion - greater co-operation between the profession and the University. It should be a condition of admission to the profession that a candidate not only knows something of the theoretical, but also of the practical side of the law. Apart from the experience gained in an office, the aspirant imbibes in the atmosphere by which he is surrounded some of those traditions which made, and respect for which alone preserves, the profession as an honourable calling, while his academic training, by inculcating a sense of the dignity of the subject with which he is dealing, will further assist in maintaining the tone of the profession.

In other ways "clerkship" - I use the expression for want of a better - would prove advantageous. It might be prescribed that before commencing the student should have to devote his whole time for a session at a University College, and, again, a premium might be 
placed on literary culture by requiring a shorter period of practical work for those who had taken an Arts degree. But apart from this there is room for improvement as things are at present. The time of many students between 8 or 9 am and 7 or $8 \mathrm{pm}$ is divided between the office work and attendance at college. Is it surprising that, physically and mentally exhausted, they seek at the end of the day adventitous aids to passing examinations and regard it as a work of supererogation to acquire more than the bare minimum of knowledge required to satisfy their examiners? Some attempt, therefore, should be made, as is made in other occupations, to reduce his day's work within reasonable limits.

Another suggestion I have to make with much greater diffidence. It is this: That it should not be thought that the door of the University is for ever closed when one has opened that of the profession. I do not for a moment mean to recommend the adoption of a practice which prevails, or used to prevail, on the Continent of Europe of seeking to enlighten, or shall I say intimidate, the Court by obtaining opinions from Universities, an exotic whose seed never took root in English soil although it was planted on at least one historic occasion. I do feel, however, that there are many occasions on which aid and assistance might be sought and given and rendered with mutual benefits if practitioners had confidence in the competency and experience of the law school. It is done in medicine and science; why not in law? When the foundation for this confidence is laid I venture to prophesy that association with the University will be sought not merely as a professional advantage, but as a distinct honour.

And here I conclude by reminding you that an American President, when he ceased to be the first citizen of a great republic, did not think it beneath his dignity to become a professor of law. During the tenure of this office he was, for a season, President of the American Bar Association, as well as President of the Institute of Jurisprudence. And he only vacated that office to take his seat as head of the Supreme Court of the United States, a tribunal which he still adorns. It is a coincidence that his immediate successor at White House had been a professor of law. 